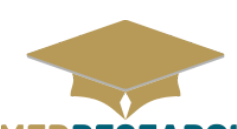

MEDRESEARCH

www.medresearch.in

\title{
A cross sectional study on internet addiction among students of KMCT integrated campus
}

\author{
Mohandas B. ${ }^{1}$, T Pawar A. ${ }^{2 *}$, John A. ${ }^{3}$, Kumar K. D. ${ }^{4}$, Sujesh P.K. \\ DOI: https://doi.org/10.17511/ijphr.2019.i1.03
}

\footnotetext{
1 Bindu Mohandas, Associate Professor, Department of Community Medicine, KMCT Medical College, Calicut, Kerala, India.

2* Anant T Pawar, Professor and HOD, Department of Community Medicine, Government Medical College, Khandwa, Madhya Pradesh, India.

3 Annie John, Professor and HOD, Department of Community Medicine, KMCT Medical College, Calicut, Kerala, India.

${ }^{4}$ Durgesh Kumar K., Statistician, Department of Community Medicine, KMCT Medical College, Calicut, Kerala, India.

5 Sujesh P.K., Medico-social worker, Department of Community Medicine, KMCT Medical College, Calicut, Kerala, India.
}

Background: College students are vulnerable for developing dependence on the Internet, more than most other segments of the society. Studies on pathological internet use in India especially Kerala are scanty. So this study was conducted to find out internet addiction among college students. Objectives: 1) To find out the prevalence of internet addiction among the college students 2) To study the pattern of internet usage among these students. Methods: This cross-sectional study was carried out in students of four different colleges under KMCT Group of Institutions in Kozhikode, Kerala 2016-17. The data was collected by self- administering questionnaire consisting of socio demographic information, internet usage and Young's Internet Addiction Test (YIAT). Data collected was entered in Microsoft excel and analyzed using SPSS. Prevalence of internet addiction was determined based on total score of YIAT. Result: The mean age of the study participants was $20.25 \pm 1.35 D$. About $48.3 \%$ were males and $51.7 \%$ females. The mean age of computer use and internet use was $10.01 \pm 3.55$ years and $6.61 \pm 3.13$ years respectively. Prevalence of internet addiction was $77.6 \%$ in mild users and $18.4 \%$ in moderate users. $49.24 \%$ accessed internet during night time. $94.86 \%$ had internet connection in their smart phones and it was the most common device used for accessing internet. $93.1 \%$ said that internet helps in improving their academics. $43.5 \%$ visited various sites for more than ten times a month for academic purposes. $14.5 \%$ visited various sites on internet when they get time in between lecture classes and $7.1 \%$ visited different sites during an ongoing lecture. Conclusion: The results highlight the vulnerability of professional college students to internet addiction.

Keywords: KMCT, SPSS, Pornography

\section{Corresponding Author}

Anant T Pawar, Professor and HOD, Department of Community Medicine, Government Medical College, Khandwa, Madhya Pradesh, India. Email: dr.anantp@gmail.com

\section{How to Cite this Article}

Mohandas B, Pawar AT, John A, Kumar KD, Sujesh PK. A cross sectional study on internet addiction among students of KMCT integrated campus. Public Health Rev Int J Public Health Res. 2019;6(1):17-24. Available From

https://publichealth.medresearch.in/index.php/ijphr/ article/view/96
To Browse

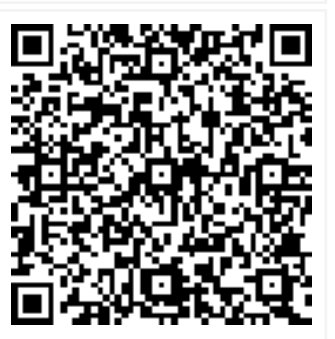

Manuscript Received 2019-02-10

Conflict of Interest No

Review Round 1
2019-02-20
Funding
Nil

Review Round 2
2019-02-25
Ethical Approval
Yes

Review Round 3

Plagiarism X-checker $5 \%$
Accepted 2019-02-28

Note

(c) 2019 by Bindu Mohandas, Anant T Pawar, Annie John, Durgesh Kumar K., Sujesh P.K. and Published by Siddharth Health Research and Social Welfare Society. This is an Open Access article licensed under a Creative Commons Attribution 4.0 International License https://creativecommons.org/licenses/by/4.0/ unported [CC BY 4.0]. 


\section{Introduction}

Today at a time 2.8 billion people are online and 5.2 billion people are on mobile, the world has become a giant, globally connected village where all information ever created is just a click away [1].

Global phenomenon of technological progress and connectivity has not spared population from developing countries due to extreme infiltration of technology even into remotest tribal areas and all citizens are converted into Netizens. India had 432 million mobile internet users in December 2016, of which 269 million (62.3\%) were from urban India and 163 million (37.7\%) were from rural India [2].

The internet was originally designed to facilitate communication and research activities. Now it is used by many to seek information and for business transactions. On the other hand, it can be used by some to indulge in pornography, excessive gaming, chatting for long hours and gambling.

There have been growing concerns worldwide for what has been labeled as "internet addiction" $[3,4]$. First time in 1995 Dr. Ivan Goldberg proposed the term "internet addiction" for pathological compulsive internet use.

Young linked excessive internet use most closely to pathological gambling, a disorder of impulse control in DSM IV and adapted the DSM IV criteria to relate to internet use in the Internet Addiction Test $[5,6]$.

Davis preferred the term "pathological internet use" (PIU) over internet addiction as addiction term mainly refers to dependency onpsychoactive substances. Scott Caplan suggested replacing the term "pathological internet use" with "problematic internet use" which is widely used allover now.

Connection of PIU between social phobia, depression, anxiety, substance abuse and self harm is well established now $[7,8,9]$. College students are vulnerable for developing dependence on the Internet, more than most other segments of the society.

This can be attributed to several factors including the following: Availability of large blocks of free time; courses that require use of gadgets and internet; the psychological and developmental characteristics of young adult hood; sudden freedom from parental control and monitoring; influence of peers; the Internet
Offering a route of escape from exam stress, allof which make Internet overuse a significant cause ofconcern for parents and faculty $[4,10,11]$.

There are innumerable studies globally depicting a worldwide scenario of the problematic internet use phenomena. But large scale epidemiological research about PIU in India especially Kerala are scanty.

Most of these studies have not covered students in professional colleges. So this study was conducted to find out patterns of internet use and prevalence of internet addiction among college students from different disciplines in Kozhikode district of Kerala.

\section{Material and Methods}

\section{Setting: KMCT Integrated Campus}

Type of study: Cross sectional study

Sampling method: Simple random sampling

Sample collection: This cross-sectional study was carried out in four different colleges across four different streams of professional courses under KMCT Group of Institutions (Medicine, Dentistry, Architecture and Pharmacy) in Kozhikode, Kerala during the year 2016-17.

The sample size was calculated using $45.8 \%$ prevalence of internet addiction observed by Krishnamurthy et al in the study conducted at Bangalore [8]. For 95\% confidence interval and $5 \%$ absolute precision the sample size required was 381 ; which was rounded off to 390 .

A total of 390 students from these four colleges were selected by simple random sampling technique. Of the total 390 students included in study, around 28 students could not be included in the study as they were not Internet users, and 31 submitted incomplete forms. Thus, a total of 331 students were finally included in the study.

Data collection: The data was collected by selfadministering predesigned and pretested structured questionnaire. The nature and purpose of the study was explained to the students and it was emphasized to choose the answer which they actually felt.

Questionnaires were distributed to the participants in the campus settings and were collected onsite after 30 minutes.

The questionnaire contained four parts: 
01. Part I included Socio demographic information including age, sex, religion, income etc.

02. Part II included details regarding patterns of internet use such as place of access, gadget used for access, internet use hours per day, frequent web activities such as gaming, chatting, shopping, social networking etc.

03. Part III included Young's Internet Addiction Test (YIAT). It is a 20-item questionnaire measured on five-pointLikert scale which is one of the most reliable scale for evaluating internet addiction.

04. Part IV included 7 item Health Questionnaire which is a self report of physical effects of internet/ electronic gadget use.

Confidentiality was assured and informed consent was taken.

Statistical methods: Data collected was entered in Microsoft excel and analyzed using the statistical package for social science (SPSS) software (version 14.0). Frequencies and percentages were calculated for all the categorical variables. Mean and Standard deviation were calculated for all numerical variables. Chi-square test was used for analyzing categorical variables. P-value $<0.05$ was considered as significant.

Scoring system: Prevalence of internet addiction was determined based on total score of YIAT. Internet use was divided into four categories normal range : $<20$ points, mild: $20-49$ points, moderate: 50-79 points, and severe: $80-100$ points

Ethical consideration and permission: The study was conducted after obtaining the approval from the Institutional Ethics Committee and permission was sought from the college authorities of all the colleges.

\section{Results}

The mean age of the study participants was $20.25 \pm 1.3 \mathrm{SD}$. Among them $48.3 \%$ were males and $51.7 \%$ were females.The mean age ofcomputer use and internet use was $10.01 \pm 3.55$ years and 6.61 \pm 3.13 years respectively.

$49.24 \%$ of the participants accessed the internet during night time. The socio demographic characteristics of the study participants are depicted in Table 1.

Table-1: Socio demographic characteristics of study participants $(n=331)$.

\begin{tabular}{|c|c|}
\hline Socio demographic characteristics & Students (\%) \\
\hline \multicolumn{2}{|l|}{ Age } \\
\hline$<20$ & $208(62.8)$ \\
\hline$>20$ & $123(37.2)$ \\
\hline \multicolumn{2}{|l|}{ Gender } \\
\hline Male & $160(48.3)$ \\
\hline Female & $171(51.7)$ \\
\hline \multicolumn{2}{|l|}{ Religion } \\
\hline Hindu & $123(37.3)$ \\
\hline Muslim & $164(49.7)$ \\
\hline Christian & $43(13)$ \\
\hline \multicolumn{2}{|l|}{ Place of stay } \\
\hline Day scholar & $118(64.4)$ \\
\hline Hostel & $213(35.6)$ \\
\hline \multicolumn{2}{|l|}{ Nativity } \\
\hline City & 56 (16.9) \\
\hline Town & $250(75.5)$ \\
\hline Village & $25(7.6)$ \\
\hline \multicolumn{2}{|l|}{ Course } \\
\hline MBBS & $177(53.47)$ \\
\hline Pharmacy & $56(16.92)$ \\
\hline BDS & $39(11.78)$ \\
\hline Architecture & $59(17.82)$ \\
\hline \multicolumn{2}{|l|}{ Parent's occupation (Father) } \\
\hline Professional & $116(35.5)$ \\
\hline Semi professional & $11(3.1)$ \\
\hline Skilled & $155(47.4)$ \\
\hline Semi skilled & $22(6.7)$ \\
\hline Unskilled & $22(6.7)$ \\
\hline Unemployed & $4(0.9)$ \\
\hline \multicolumn{2}{|l|}{ Parent's occupation (Mother) } \\
\hline Professional & $71(21.6)$ \\
\hline Skilled & $3(0.9)$ \\
\hline Semi skilled & $4(1.2)$ \\
\hline Unskilled & $3(0.9)$ \\
\hline Housewife & 249 (75.9) \\
\hline \multicolumn{2}{|l|}{ Gadgets used } \\
\hline Mobile & $158(46.4)$ \\
\hline Tablet & $3(0.6)$ \\
\hline Laptop/ desktop & $8(2.4)$ \\
\hline More than one device & $162(49.1)$ \\
\hline
\end{tabular}

Table-2: Pattern of internet use by the study participants $(n=331)$.

\begin{tabular}{|l|l|}
\hline \multicolumn{1}{|c|}{ Variables } & \multicolumn{1}{|c|}{ Number (\%) } \\
\hline Years of computer use & $8(2.1)$ \\
\hline$<2$ & $32(9.7)$ \\
$2-5$ & $73(22.1)$ \\
$5-8$ & $218(62.1)$ \\
$>8$ & $314(94.86)$ \\
\hline Device commonly used to access internet \\
\hline Mobile phone & $17(5.13)$ \\
\hline
\end{tabular}




\begin{tabular}{|c|c|}
\hline \multicolumn{2}{|l|}{ Years of internet use } \\
\hline$<2$ & $26(7.9)$ \\
\hline $2-5$ & 95 (28.7) \\
\hline $5-8$ & $132(39.9)$ \\
\hline$>8$ & $78(23.6)$ \\
\hline \multicolumn{2}{|l|}{ Monthly expense for internet } \\
\hline$<200$ & $170(53.1)$ \\
\hline $200-500$ & $69(21.6)$ \\
\hline $500-800$ & $44(13.8)$ \\
\hline$>800$ & 37 (11.6) \\
\hline \multicolumn{2}{|c|}{ Most common location of internet access } \\
\hline Home & $143(43.6)$ \\
\hline Hostel & $97(29.6)$ \\
\hline Campus & $4(1.2)$ \\
\hline Library & $3(0.9)$ \\
\hline Cybercafé & $4(1.2)$ \\
\hline Public places & $11(3.4)$ \\
\hline Accessing at more than one location & $67(20.1)$ \\
\hline \multicolumn{2}{|l|}{ Time of access } \\
\hline Morning & $5(1.51)$ \\
\hline Afternoon & $16(4.83)$ \\
\hline Evening & $135(40.78)$ \\
\hline Night & $163(49.24)$ \\
\hline No specific time & $12(3.62)$ \\
\hline \multicolumn{2}{|l|}{ Frequency of internet use } \\
\hline Daily & $177(53.2)$ \\
\hline Alternative days & $59(17.5)$ \\
\hline 1-2 times a week & $52(16)$ \\
\hline$<5$ times a month & $43(13.2)$ \\
\hline \multicolumn{2}{|l|}{ IAT Score } \\
\hline$<20$ & $7(2.2)$ \\
\hline $20-49$ & $257(79.1)$ \\
\hline $50-79$ & $61(18.8)$ \\
\hline $80-100$ & $0(0)$ \\
\hline
\end{tabular}

$94.86 \%(314 / 331)$ of the study participants had internet connection in their smart phones and it was the most common device used for accessing internet. $49.1 \%(162 / 331)$ of them possess at least two gadgets and they feel proud of it while using the device in front of others.

In the past five years, $19.93 \%$ (66/331) spent less than Rs.10000 for buying gadgets, $21.75 \%$ (72/331) spent Rs.10000 - 25000, 25.98\% (86/331) spent Rs.25000-50000, 22.35\% (74/331) spent Rs.50000-100000 and 9.66\% (32/331) spent more than Rs. 100000 for purchasing gadgets.

Characteristics and pattern of internet use by the study participants is depicted in Table $2.93 .1 \%$ (308/331) of the study participants said that internet helps in improving their academics.

$43.5 \%(143 / 331)$ of the students said they visit
Various sites for more than ten times a month for academic purposes. $35.9 \%(118 / 331)$ of them visited $1-5$ times and $15.2 \%(50 / 331)$ of them visited 5-10 times a month for academic purposes. $5.4 \%$ (18/331) doesn't use internet for academic purposes.

$14.5 \%(47 / 331)$ of the students said that they visit various sites on internet when they get time in between lecture classes and 7.1\% (23/331) of them agreed that they visit different sites during an ongoing lecture.

Table-3: Comparison of IAT Score with various student characteristics.

\begin{tabular}{|c|c|c|c|c|c|}
\hline & & \multicolumn{3}{|c|}{ Test score } & \multirow[t]{2}{*}{$P$ value } \\
\hline & & $<20$ & $20-49$ & $50-79$ & \\
\hline \multirow[t]{2}{*}{ Tingling } & Yes & 1 & 22 & 15 & \multirow[t]{2}{*}{0.005} \\
\hline & No & 6 & 25 & 46 & \\
\hline \multirow[t]{2}{*}{ Head ache } & Yes & 0 & 69 & 23 & \multirow[t]{2}{*}{0.024} \\
\hline & No & 7 & 188 & 38 & \\
\hline \multirow[t]{2}{*}{ Watering eye } & Yes & 1 & 37 & 20 & \multirow[t]{2}{*}{0.006} \\
\hline & No & 6 & 220 & 41 & \\
\hline \multirow[t]{2}{*}{ Back pain } & Yes & 2 & 42 & 25 & \multirow[t]{2}{*}{0.001} \\
\hline & No & 5 & 214 & 36 & \\
\hline \multirow[t]{2}{*}{ Neck pain } & Yes & 1 & 19 & 15 & \multirow[t]{2}{*}{0.002} \\
\hline & No & 6 & 238 & 46 & \\
\hline \multirow[t]{2}{*}{ Game time } & $\mid<1$ & 7 & 151 & 32 & \multirow[t]{2}{*}{0.020} \\
\hline & $>1$ & 0 & 52 & 20 & \\
\hline \multirow[t]{2}{*}{ Expense } & $<800$ & 5 & 220 & 52 & \multirow[t]{2}{*}{0.661} \\
\hline & $>800$ & 1 & 27 & 9 & \\
\hline \multirow[t]{2}{*}{ Sex } & Male & 3 & 114 & 41 & \multirow[t]{2}{*}{0.005} \\
\hline & Female & 4 & 143 & 20 & \\
\hline \multirow[t]{2}{*}{ Age } & $<20$ & 4 & 156 & 44 & \multirow[t]{2}{*}{0.220} \\
\hline & $>20$ & 3 & 101 & 17 & \\
\hline \multirow[t]{4}{*}{ Branch } & MBBS & 3 & 141 & 32 & \multirow[t]{4}{*}{0.027} \\
\hline & Pharmacy & 3 & 43 & 8 & \\
\hline & Architecture & 1 & 37 & 18 & \\
\hline & Dental & 0 & 36 & 3 & \\
\hline \multirow[t]{2}{*}{ Stay } & Hostler & 5 & 160 & 45 & \multirow[t]{2}{*}{0.223} \\
\hline & Day scholar & 2 & 97 & 16 & \\
\hline
\end{tabular}

$77.6 \%(257 / 331)$ of the students play games in their gadgets. Only $20.5 \%$ (68/331) play online games. $72.6 \%$ (193/331) of them play for less than an hour whereas $19.2 \%$ (51/331) of them play for 1-2 hours. $8.3 \%(22 / 331)$ of the students play games more than two hours.

$1.5 \%(6 / 331)$ of the students updates their display picture (DP) daily in social networking sites. $28 \%$ (92/331) of them update DP at least 2-3 times a week and $17.5 \%(58 / 331)$ updates $1-2$ times a month. $46.2 \%(152 / 331)$ of them rarely changes 
Their display picture whereas $6.8 \%(23 / 331)$ of them have never done this so far.

Students those who were using internet daily for long duration was suffering from headache $(28.3 \%)$, neck pain $(10.2 \%)$, back pain $(21.3 \%)$, eye pain $(22.2 \%)$, watering of eyes $(17.8 \%)$ and tingling sensation in hands (11.7\%); and the symptoms were significantly associated with the internet addiction test scoreie, $2.2 \%$ of them were normal users, $79.1 \%$ were having mild addiction, $18.8 \%$ were moderately addicted and none in the category of severe addiction (Table 3). Prevalence of internet addiction was $77.6 \%$ in mild users and $18.4 \%$ in moderate users (Table 4).

Table-4: Prevalence of internet addiction.

\begin{tabular}{|l|l|l|l|}
\hline Types of prevalence & YIAT score & Frequency & Prevalence \\
\hline Mild & $20-49$ & 257 & 77.6 \\
\hline Moderate & $50-79$ & 61 & 18.4 \\
\hline
\end{tabular}

\section{Discussion}

College students are vulnerable for developing dependence on the internet, more than most other segments of the society. This can be attributed to several factors like availability of large blocks of free time; courses that require use of gadgets and internet; the psychological and developmental characteristics of young adult hood; sudden freedom from parental control and monitoring; influence of peers; the internet offering a route of escape from exam stress, all of which make internet overuse a significant cause of concern for parents and faculty.

Professional course students are particularly vulnerable group on account of the time they spend on internet $[6,7,9]$. Observing these factors, it is important to study internet addiction in this subset of population. This study is an attempt to understand the degree of internet addiction among professional course students in KMCT Integrated campus.

The mean age of the study participants was $20.25 \pm$ 1.34 SD. The mean age of computer use and internet use was $10.01 \pm 3.55$ years and $6.61 \pm$ 3.13 years respectively. The male students were observed to be more addicted to the internet than the female students $(p=0.005)$.

Sharma A, et al. in their study of internet addiction among professional course students in Jabalpur city of Madhya Pradesh observed male students to be more addicted to Internet than the female students
(X2=22.673, $P=0.000)$ [10].

Grover, et al. in their study, a survey of Internet use pattern among professionals in India, reported similar result[11]. A study on Internet addiction among adolescents revealed $50 \%$ increased odds for males to be addicted to the Internet ( $O R=1.5$, $95 \% \mathrm{CI}=1.1-2.2)$ when compared with females [12].

In our study internet addiction was assessed using Young's internet addiction scale; $2.2 \%$ of them were normal users, $79.1 \%$ were having mild addiction, $18.8 \%$ were moderately addicted and none in the category of severe addiction.

This finding was similar to the results of the study conducted by Sharma A et al, where they found $57.3 \%$ students were normal users while $35.0 \%$ cases have mild addiction, $7.4 \%$ students have moderate addiction and $0.3 \%$ of them have severe addiction to internet, so, combining mild, moderate and severe addictions, a total of $42.7 \%$ students were addicted to internet [10].

A study on the prevalence of internet addiction in Indian adolescents by Goel $\mathrm{D}$ et al, reported the prevalence of $0.7 \%$ [7]. Chathoth $V \mathrm{M}$ et al, reported prevalence of internet addiction (representing moderate and severe addiction) as $18.88 \%$ in undergraduate medical students in Mangalore [13]. A study on internet addiction disorder among medical students in China by Liu $X$ et al, reported a prevalence of $16.2 \%$ [14].

In our study students those who were using internet daily for long duration was suffering from headache $(28.3 \%)$, neck pain $(10.2 \%)$, back pain $(21.3 \%)$, eye pain $(22.2 \%)$, watering of eyes $(17.8 \%)$ and tingling sensation in hands $(11.7 \%)$; and the symptoms were significantly associated with the internet addiction test score ie, $2.2 \%$ of them were normal users, $79.1 \%$ were having mild addiction, $18.8 \%$ were moderately addicted and none in the category of severe addiction.

The study on prevalence and associated risk factors of internet addiction in college going students in Nanded city by Surwase $\mathrm{K}$ et al showed statistically significant association between internet addiction and psychological disposition of the study participants [6].

The most common device used to access the internet was smart phones $(94.86 \%)$ in this study. There was a significant difference $(p=0.027)$ present between students of various professional 
Courses in being addicted to the Internet.

Significant relationship was also found between time spent on using internet per day and internet addiction $(p=0.022)$ in our study.

The study of internet addiction among professional course students by Sharma A et al, only $46.5 \%$ students used smart phones to access internet. Also they found there was a significant difference present between students of various courses in being addicted to the Internet $(p=0.010)$.

Significant relationship was also found between time spent on using internet per day and internet addiction $(p=0.000)$ in their study [10].

Heterogeneous representation of college students and their systematic method in selection of samples tried to avoid bias in our study as participants were recruited from colleges with different academic settings.

However, recall bias could not be ruled out because it was a cross sectional study and participants were asked to report details of past exposure to use of internet; also they were self reporting and might have responded in such a way as to showthemselves in a good light.

\section{Conclusion}

In the last decade, internet has become an integral part of our life. The results highlight the vulnerability of professional college students to internet addiction. Prevalence of internet addiction using Young's internet addiction test is $77.64 \%$ in mild usersand $15.64 \%$ in moderate users.

Duration of internet use plays an important role in developing internet addiction. Internet is increasing and internet addiction seems to rise in future. Awareness should be created among the students to improve ability to reduce the occurrence of internet addictionbehaviour promoting their healthy growth.

\section{Reference}

01. Pezoa-Jares RE, Espinoza-Luna IL, VasquezMedina JA. Internet Addiction- A Review. J Addict Res Ther. 2012;Nov;6(4). doi: [Article] [Crossref]

02. Vidyachathoth, Kodavanji B, Kumar NA, Pai SR. Correlation between Affect and Internet Addicti -on in Undergraduate Medical Students in Mang -alore. J Addict Res Ther. 2014;Feb;5(1)1-4. doi: [Article] [Crossref]
03. Bahrainian SA, Alizadeh $\mathrm{KH}$, Raeisoon MR, et al. Relationship of Internet addiction with selfesteem and depression in university students. J Prev Med Hyg. 2014 Sep;55(3)86-9. [Crossref]

04. Salehi M, Norozi Khalili M, Hojjat SK, et al. Prevalence of internet addiction and associated factors among medical students from Mashhad, Iran in 2013. Iran Red Crescent Med J. 2014 May;16(5)e17256.

doi: 10.5812/ircmj.17256. Epub 2014 May 5 [Crossref]

05. Young K. Assessment of internet addiction. Available from: https://gamedependencia. files. wordpress.com/2013/06/young-assessment-ofinternet-addiction.pdf [Crossref]

06. Surwase K, Bagdey P, Adikane H. Prevalence and Associated Risk Factors of Internet Addiction in College Going Students in Nanded city. Natl J Community Med. 2017 May; 8(5)213-218.

[Crossref]

07. Goel D, Subramanyam A, Kamath R. A study on the prevalence of internet addiction and its association with psychopathology in Indian adolescents. Indian J Psychiatry. 2013 Apr; 55 (2) 140-3.

doi: 10.4103/0019-5545. 111451 [Crossref]

08. Krishnamurthy S, Chetlapalli SK. Internet addiction- Prevalence and risk factors- A crosssectional study among college students in Bengaluru, the Silicon Valley of India. Indian J Public Health. 2015;Apr-Jun;59(2)115-21. doi: $10.4103 / 0019-557 \quad \times .57531 \quad$ [Crossref]

09. Sharma KD, Gupta ID, Gunjan, Sharma V, Sharma R, Sharma D. Internet addiction pattern among high school students of Jaipur city- a descriptive study. International Multispeciality Journal of Health. 2016; May;2(5)25-31. Available from: [Article] [Crossref]

10. Sharma A, Sahu R, Kasar PK, Sharma R. Internet addiction among professional courses students- A study from Central India. Int J Med Sci Public Health. 2014;Jun;3(9)1069-73. DOI: $10.5455 /$ ijmsph. 2014. 180620142 [Crossref] 
11. Grover S, Chakraborty K, Basu D. Pattern of Internet use among professionals in IndiaCritical look at a surprising survey result. Ind Psychiatry J. 2010;Jul;19(2)94-100. doi: [Article] [Crossref]

12. Lam LT, Peng ZW, Mai JC, et al. Factors associated with Internet addiction among adolescents. Cyberpsychol Behav. 2009; Oct; 12(5)551-5. doi: [Article] [Crossref]
13. Chathoth VM, Kodavanji B, Nayanatara AK, Pai $\mathrm{SR}$. Internet behaviour pattern in undergraduate medical students in Mangalore. International Journal of Innovative Research in Science, Engineering and Technology. 2013; Jun;2(6)2133. Available from: [Article] [Crossref]

14. Liu X, Bao Z, Wang Z. Internet Use and Internet Addiction Disorder Among Medical Students- A Case from China. Asian Social Science. 2010;Jan;6(1)28-34.

DOI: [Article] [Crossref] 